\title{
PROSEDUR MENYELESAIKAN KASUS HUKUM DENGAN IJMAK
}

\author{
Sarpini
}

IAIN Purwokerto, Jawa Tengah, Indonesia

sarpini@iainpurwokerto.ac.id

\author{
Received:01-04-2019; Revised:05-05-2019; Accepted: 07-06-2019
}

\begin{abstract}
There are mufties who recognize ijmak and there are some who still disagree on the existence of ijmak and their jurisdiction to be used as a source in legal proceedings. Some groups believe that ijmak, which can be used as proof, namely ijmak, which occurs among only friends and some scholars, have argued that ijmak can still be done in the days after a friend. Especially in the present, new problems that require answers, so that ijmak or istinbat law by way of deliberation is needed which will later find a bright spot in solving the problem. The purpose of this study is to know and understand the meaning of ijmak, know and understand the legal basis of ijmak, know and understand references of ijmak, know and understand the distribution of ijmak, know and understand the controversy of ijmak, know and understand Examples of disputes caused by ijmak controversy, and know and understand procedures for resolving legal cases with ijmak. This research method is descriptive analysis, namely the author describes all data about the ijmakkem then do an analysis of the data to obtain a conclusion. The results of this study conclude that the procedure for resolving legal cases with ijmak, namely consensus or ijmaks for centuries has become the most important validation of various decisions in Islam, especially among Sunnis. In fact, in Sunni circles, the final authority for religious interpretation is put on consensus (ijmak) or the collective verdict of Muslim society. The implication is that consensus plays an important role in the development of Islam and contributes significantly to its interpretation.
\end{abstract}

Keywords: ijmak, mujtahid, istinbat.

\section{ABSTRAK}

Ulama ada yang mengakui ijmak dan ada beberapa yang masih tidak sepakat adanya ijmak serta kehujjahannya untuk dijadikan sumber dalam pengambilan hukum. Beberapa kelompok meyakini bahwa ijmak yang bisa dijadikan hujjah yaitu ijmak yang terjadi di kalangan sahabat saja dan beberapa ulama ada yang berargumentasi bahwa ijmakmasih bisa dilakukan pada masa-masa setelah sahabat.Apalagi pada masa sekarang yang bermunculan permasalahan baru yang membutuhkan jawaban, sehingga ijmak atau istinbat hukum dengan jalan musyawarah sangat diperlukan yang nantinya akan menemukan titik terang dalam menyelesaikan persoalan. Tujuan penelitian ini yaitu untuk mengetahui dan memahami cara menyelesaikan masalah hukum dengan ijmak. Metode penelitian ini bersifat analisis deskriptif, yaitu penulis memaparkan semua data tentang ijmak kemudian melakukan analisis terhadap data untuk memperoleh sebuah kesimpulan. Hasil penelitian ini menyimpulkan bahwa prosedur menyelesaikan kasus hukum dengan ijmak yaitu konsensus atau ijmak selama berabad-abad telah menjadi validasi terpenting berbagai keputusan di dalam Islam, khususnya di kalangan Sunni. Bahkan, di kalangan Sunni, otoritas final untuk penafsiran keagamaan diletakkan pada konsensus (ijmak) atau putusan kolektif masyarakat muslim. 
Implikasinya, konsensus memainkan peran penting dalam perkembangan Islam dan memberi andil yang signifikan terhadap penafsirannya.

Kata kunci: ijmak, mujtahid, istinbat.

\section{A. PENDAhULUAN}

Hukum syariat Islam tidak semuanya gamblang terdapat dalam al-Qur'an dan alHadist,tetapi ada juga masalah-masalah yang muncul terutama dalam masalah fikih yang batasan hukumnya tidak terdapat dalam al-Qur'an dan al-Hadis. Hukum yang pasti adalah hukum yang sudah jelas di dalam al-Qur'an dan al-Hadis seperti wajibnya shalat puasa zakat dan lain sebagainya. Sedangkan hukum yang tidak terdapat dalam al-Qur'an dan al-Hadis perlu diadakan ijmak atau qiyas supaya hukum tersebut jelas menurut syariat Islam (Rosyada, 1996).

Pada masa selanjutnya muncul kejadian-kejadian baru yang tidak ada pada masa Rasulullah, maka ada metode-metode baru dalam pengambilan hukum, tetapi masih berdasar kepada Al-Qur'an dan Al-Hadis. Untuk itulah diperlukan pengkajianpengkajian yang mendalam yang harus dilakukan oleh para ulama-ulama ahli fikih. Para ulama dituntut untuk bisa mengkaji Al-Qur'an dan Al-Hadis agar bisa menentukan hukum-hukum tentang suatu perkara dalam kehidupan yang dulunya belum pernah terjadi.

Berdasarkan perkara itulah para ulama bersepakat untuk membuat suatu dasar kekuatan hukum yang kekuatannya di bawah Al-Qur'an dan Al-Hadis. Dasar hukum inilah yang kemudian dikenal dengan istilah Ijmak. Ijmak muncul setelah Rasulullah wafat, para sahabat melakukan ijtihad untuk menetapkan hukum terhadap masalahmasalah yang mereka hadapi. Khalifah Umar Ibnu Khattab misalnya selalu mengumpulkan para sahabat untuk berdiskusi dan bertukar fikiran dalam menetapkan hukum, jika mereka telah sepakat pada satu hukum, maka ia menjalankan pemerintahan berdasarkan hukum yang telah disepakati (Hasan, 1985).

Ijma' sebagaimana didefinisikan oleh sebagian besar ulama Ushul adalah kesepakatan seluruh ulama mujtahid dari kaum muslimin pada suatu masa sesudah wafat Rasulullah SAW atas suatu hukum syara' pada suatu kejadian (lihatKhalaf, 1994).

Meskipun ijmakmempunyai peran dan posisi yang sangat strategis dalam hukum Islam, tetapi ia tidak lepas dari beberapa kritik yang dilontarkan oleh para ulama. Barangkali hanya pada masa Al-Syaikhaini (kholifah Abu Bakar dan Umar) saja terjadi ijmak. Setelah itu, walaupun terjadi ijmak, kemungkinan melalui metode pengambilan dalil, landasan ijmakpun tidak lepas dari berbagai kritik dan komentar. Ketegasan ijmakdalam ayat al-Qur'an tersebut masih diragukan, demikian juga Hadis yang menjadi pijakan ijmak hanyalah pada tingkatan ahad.

Berdasarkan uraian yang telah dikemukan pada latar belakang masalah tersebut diatas, dapat dikemukakan perumusan masalah yaitu bagaimana cara menyelesaikan masalah hukum dengan ijmak.

\section{B. METODE PENELITIAN}

Metode penelitian dalam penulisan ini adalah penelitian kualitatif deskriptif dengan pendekatan studi kepustakaan, yang akan menjelaskan tentang ijmak. Penelitian deskriptif kualitatif ditujukan untuk mendeskripsikan dan menggambarkan fenomenafenomena yang ada, baik bersifat alamiah maupun rekayasa manusia, yang lebih memperhatikan mengenai karakteristik, kualitas, keterkaitan antar kegiatan (Nana Syaodih Sukmadinata, 2011).Jenis data yang digunakan dalampenulisan karya ilmiah ini adalah data sekunder. Sumber data yang dimaksud adalah jurnal-jurnal yang diperoleh 
dari hasil penelusuran di internet serta buku-buku mengenai ijmak. Penggunaan data sekunder dalam penelitian ini memberikan beberapa keuntungan terutama terkait waktu dan biaya penelitian.

\section{HASIL DAN PEMBAHASAN}

\section{Pengertian ijmak}

Secara etimologi, ijmak(الإجماع) berarti kesepakatan atau konsesnsus (Syafe'i, 2007).Ijmakjuga berarti (العزم على شيء) ketetapan hati untuk melakukan sesuatu. Perbedaan antara pengertian pertama dengan yang kedua terletak pada kuantitas (jumlah) orang yang berketetapan hati. Pengertian pertama mencukupkan satu tekad saja sedangkan untuk pengertian kedua memerlukan tekad kelompok (Syarifuddin,2009).

Secara terminologi, ada beberapa rumusan ijmakyang dikemukakan oleh para ulamausul al-fiqh. Jumhur ulamausul al-fiqh sebagaimana dikutip oleh Wahbah Zuhaili(al-Zuhayli,1986), Abu Zahrah dan Wahhab Khalaf merumuskan ijmakdengan kesepakatan para mujtahid dari umat Muhammad pada suatu masa setelah wafatnya beliau terhadap suatu hukum syara', dan Abu Zahrah menambahkan diakhir definisinya dengan "yang bersifat amaliyah" (Zahrah, 2010).

\section{Dasarhukumijmak}

Dasar hukum ijmak(Hasan, 1985) berupa aI-Qur'an, al-Hadits dan akal pikiran (Syahar, 1999).

a. Al-Qur'an

Allah SWT berfirman:

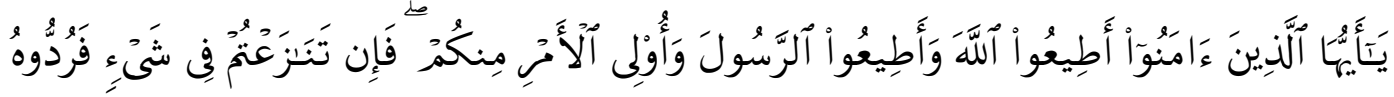

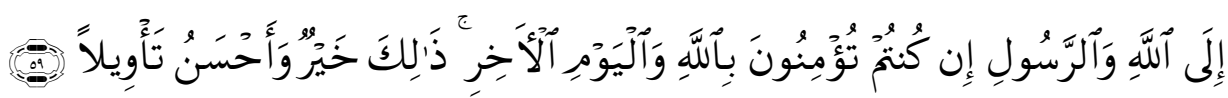

Artinya: "Hai orang-orang yang beriman, taatilah Allah dan taatilah Rasul-Nya dan ulil amri diantara kamu." (Q.S An-Nisa: 59)

Perkataan amri yang terdapat pada ayat di atas berarti hal, keadaan atau urusan yang bersifat umum meliputi urusan dunia dan urusan agama. Ulilamri dalam urusan dunia ialah raja, kepala negara, pemimpin atau penguasa, sedang ulil amri dalam urusan agama ialah para mujtahid (Umar,1985).

Berdasarkanayat di atas dipahami bahwa jika para ulilamri itu telah sepakat tentang sesuatu ketentuan atau hukum dari suatu peristiwa, maka kesepakatan itu hendaklah dilaksanakan dan dipatuhi oleh kaum muslimin.

Firman AIlah SWT:

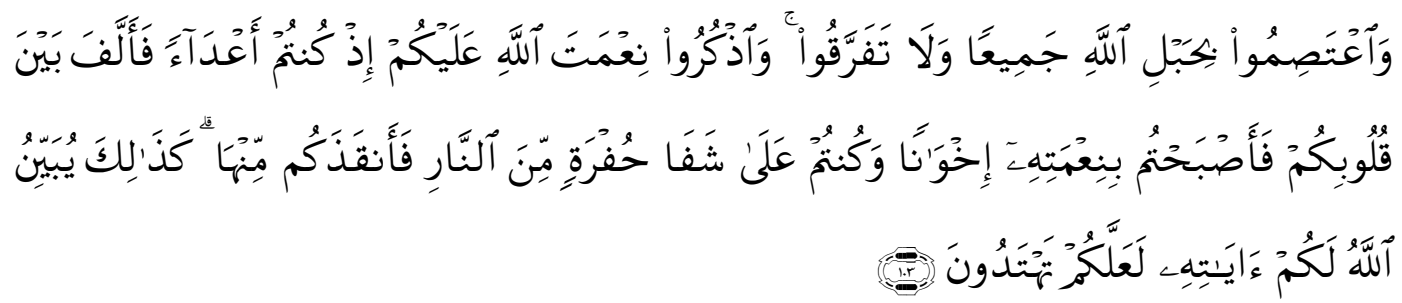

Artinya: "Dan berpeganglah kamu semuanya kepada tali (agama) Allah dan janganlah kamu bercerai-berai." (Ali Imran: 103).

Ayat ini memerintahkan kaum muslimin bersatu padu, jangan sekali-kali bercerai-berai. Termasuk dalam pengertian bersatu itu ialah berijmak (bersepakat) 
dan dilarang bercerai-berai, yaitu dengan menyalahi ketentuan-ketentuan yang telah disepakati oleh para mujtahid.

Firman Allah SWT:

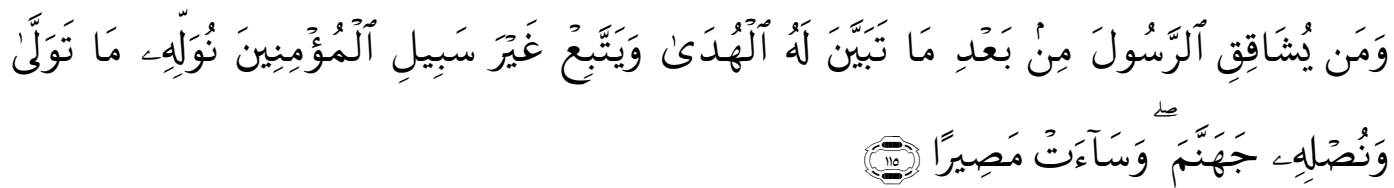

Artinya: "Dan barangsiapa yang menantang Rasul setelah jelas kebenaran baginya dan mengikuti jalan yang bukan jalan orang-orang yang beriman, Kami biarkan ia berkuasa terhadap kesesatan yang telah dikuasainya itu dan Kami masukan ia ke dalam jahannam dan jahannam itu seburuk-buruk tempat kembali." (an-Nisa: 115)

Pada ayat di atas terdapat perkataan sabililmukminina yang berarti jalan orangorang yang beriman. Jalan yang disepakati orang-orang beriman dapat diartikan dengan ijmak, sehingga maksud ayat ialah: "barangsiapa yang tidak mengikuti ijmak para mujtahidin, mereka akan sesat dan dimasukkan ke dalam neraka" (Umar,1985).

b. AI-Hadits

Bila para mujtahid telah melakukan ijmak tentang hukum syara' dari suatu peristiwa atau kejadian, maka ijmakitu hendaklah diikuti, karena mereka tidak mungkin melakukan kesepakatan untuk melakukan kesalahan apalagi kemaksiatan dan dusta, sebagaimana sabda Rasulullah SAW:

$$
\text { لا تجنمع أمنى على الخطاء و لا تجتمع أمتى على الضلالة }
$$

Artinya: "umatku tidak akan bersepakat untuk melakukan kesalahan." (HR. Abu Daud dan Tirmidzi)(Syahar, 1999).

c. Akal pikiran

Setiap ijmakyang dilakukan atas hukum syara', hendaklah dilakukan dan dibina atas asas-asas pokok ajaran Islam. Karena itu setiap mujtahid dalam berijtihad hendaklah mengetahui dasar-dasar pokok ajaran Islam, batas-batas yang telah ditetapkan dalam berijtihad serta hukum-hukum yang telah ditetapkan(Syahar, 1999).

Bila ia berijtihad dan dalam berijtihad itu ia menggunakan $\left.n a s_{\}} s\right\}$, maka ijtihadnya tidak boleh melampaui batas maksimum dari yang mungkin dipahami dari nass itu. Sebaliknya jika dalam berijtihad, ia tidak menemukan satu nasspun yang dapat dijadikan dasar ijtihadnya, maka dalam berijtihad ia tidak boleh melampaui kaidah-kaidah umum agama Islam, karena itu ia boleh menggunakan dalil-dalil yang bukan nassseperti qiyas, istihsan dan sebagainya(Al 'Alwani, 1990). Jika semua mujtahid telah melakukan seperti yang demikian itu, maka hasil ijtihad yang telah dilakukannya tidak akan jauh menyimpang atau menyalahi alQur'an dan al-Hadits, karena semuanya dilakukan berdasar petunjuk kedua dalil ltu. Jika seorang mujtahid boleh melakukan seperti ketentuan di atas, kemudian pendapatnya boleh diamalkan, tentulah hasil pendapat mujtahid yang banyak yang sama tentang hukum suatu peristiwa lebih utama diamalkan.

\section{Rukun-Rukun ijmak}

Berdasarkandefinisi dan dasar hukum ijmak di atas, maka ulama usul alfiqhmenetapkan rukun-rukun ijmak sebagai berikut:

a. Harus ada beberapa orang mujtahid dikala terjadinya peristiwa dan para mujtahid itulah yang melakukan kesepakatan (menetapkan hukum peristiwa itu. Seandainya tidak ada beberapa orang mujtahid di waktu terjadinya suatu peristiwa tentulah 
tidak akan terjadi ijmak, karena ijmakitu harus dilakukan oleh beberapa orang.(Syarifuddin,2009).

b. Yang melakukan kesepakatan itu hendaklah seluruh mujtahid yang ada dalam dunia Islam. Jika kesepakatan itu hanya dilakukan oleh para mujtahid yang ada pada suatu negara saja, maka kesepakatan yang demikian belum dapat dikatakan suatu ijmak (Khallaf, 1999).Kesepakatan itu harus dinyatakan secara tegas oleh setiap mujtahid bahwa ia sependapat dengan mujtahid-mujtahid yang lain tentang hukum (syara') dari suatu peristiwa yang terjadi pada masa itu. Jangan sekali-kali tersirat dalam kesepakatan itu unsur-unsur paksaan, atau para mujtahid yang diharapkan kepada suatu keadaan, sehingga ia harus menerima suatu keputusan. Kesepakatan itu dapat dilakukan dengan berbagai cara, seperti dengan pernyataan lisan, dengan perbuatan atau dengan suatu sikap yang menyatakan bahwa ia setuju atas suatu keputusan hukum yang telah disetujui oleh para mujtahid yang lain (Rosyada, 1996). Tentu saja keputusan yang terbaik ialah keputusan sebagai hasil suatu musyawarah yang dilakukan para mujtahid. Kesepakatan itu hendaklah merupakan kesepakatan yang bulat dari seluruh mujtahid. Seandainya terjadi suatu kesepakatan oleh sebahagian besar mujtahid yang ada, maka keputusan yang demikian belum pasti ke taraf ijmak. Ijmak yang demikian belum dapat dijadikan sebagai hujjah syari'ah (Rosyada, 1996).

\section{Proses Terjadinya ijmak}

Para ulama berbeda pendapat tentang kemungkinan adanya ijmak dan kewajiban melaksanakannya. Jumhur berkata, "ijmak itu bisa terjadi bahkan telah terlaksana". Sedangkan pengikut Nizam dan golongan Syi'ah menyatakan, ijmak itu tidak mungkin terjadi, dengan mengemukakan beberapa argumen, antara lain (Syafe'i, 2007):

Pertama, sesungguhnya ijmak yang dimaksudkan oleh jumhur tentang diharuskannya adanya kesepakatan semua mujtahid pada suatu masa sehingga harus memenuhi dua kriteria:

a. Mengetahui karakter setiap mujtahid yang dikategorikan mampu untuk mengadakan ijmak.

b. Mengetahui pendapat masing-masing mujtahid tentang permasalahan tersebut(alKhudhari Biek, 2007).

Kedua, ijmak itu harus bersandarkan kepada dalil, baik yang qat'i ataupun yang zanni. Bila berlandaskan pada dalil qat'imaka tidak diragukan lagi bahwa hal itu tidak membutuhkan ijmak. Sebaliknya bila didasarkan pada dalil yang zanni dapat dipastikan para ulama akan berbeda pendapat karena masing-masing mujtahid akan mengeluarkan pendapatnya dengan kemampuan berfikir daya nalar mereka, disertai berbagai dalil yang menguatkan pendapat mereka.

Pada masa Rasulullah SAW, beliau merupakan sumber hukum. Setiap ada peristiwa atau kejadian, kaum muslimin mencari hukumnya pada al-Qur'an yang telah diturunkan dan hadits yang telah disabdakan oleh Rasulullah SAW. Jika mereka tidak menemukannya dalam kedua sumber itu, mereka langsung menanyakannya kepada Rasulullah. Rasululah ada kalanya langsung menjawabnya, ada kalanya menunggu ayat al-Qur'an turunkan Allah SWT. Karena itu kaum muslimin masih satu, belum nampak perbedaan pendapat yang menetapkan hukum suatu peristiwa atau kejadian yang mereka alami (Umar,1985).

Setelah Rasulullah SAW meninggal dunia, kaum muslimin kehilangan tempat bertanya, namun mereka telah mempunyai pegangan yang lengkap, yaitu al-Qur'an dan al-Hadits. Jika ada kejadian atau peristiwa yang memerlukan penetapan hukum, mereka berijtihad, tetapi belum ada bukti yang nyata bahwa mereka telah berijmak. 
Seandainya ada ijmak itu, kemungkinan terjadi pada masa khalifah Abu Bakar, Khalifah Umar atau sedikit kemungkinan pada masa enam tahun pertama Khalifah Utsman. Hal ini adalah karena pada masa itu kaum muslimin masih satu, belum ada perbedaan pendapat yang tajam diantara kaum muslimin, di samping daerah Islam belum begitu luas, masih mungkin mengumpulkan para sahabat atau orang yang dipandang sebagai mujtahid.

Setelah enam tahun bahagian kedua kekhalifahan Utsman, mulailah nampak gejala-gejala perpecahan di kalangan kaum muslimin. Hal ini dimulai dengan tindakan Utsman mengangkat anggota keluarganya sebagai penjabat jabatan-jabatan penting dalam pemerintahan (nepotisme). Setelah Khalifah Utsman terbunuh, perpecahan di kalangan kaum muslimin semakin terjadi, seperti peperangan antara Ali bin Abi Thalib dengan Mu'awiyah bin Abu Sofyan, peperangan antara Ali bin Abi Thalib dengan Aisyah yang terkenal dengan perang Jamal, timbul golongan Khawarij, golongan Syi'ah golongan Mu'awiyah dan sebagainya. Demikianlah perselisihan dan perpecahan itu terjadi pula semasa dinasti Amawiyah, semasa dinasti Abbasiyah, semasa dinasti Fathimiyah dan sebagainya, sehingga dana dan tenaga umat Islam terkuras dan habis karenanya.

Di samping itu daerah Islam semakin luas, sejak dari Asia Tengah (Rusia Selatan sekarang) sampai kebagian tengah benua Afrika, sejak ujung Afrika Barat sampai Indonesia, Tiongkok Selatan, Semenanjung Balkan dan Asia Kecil. Karena itu amat sukar melakukan ijmak dalam keadaan dan luas daerah yang demikian.

Ijmak mungkin terjadi pada masa Khalifah Abu Bakar, Khalifah Umar bin Khattab, dan enam tahun pertama Khalifah Utsman; dan Setelah masa enam tahun kedua pemerintahan Khalifah Utsman sampai saat ini tidak mungkin terjadi ijmaksesuai dengan rukun-rukun yang telah ditetapkan di atas, mengingat keadaan kaum muslim yang tidak bersatu serta luasnya daerah yang berpenduduk Islam.

Pada masa sekarang telah banyak berdiri negara-negara Islam yang berdaulat atau suatu negara yang bukan negara Islam tetapi penduduknya mayoritas beragama Islam atau minoritas penduduknya beragama Islam. Pada negara-negara tersebut sekalipun penduduknya minoritas beragama Islam, tetapi ada peraturan atau undangundang yang khusus bagi umat Islam. Misalnya India, mayoritas penduduknya beragama Hindu, hanya sebagian kecil yang beragama Islam. Tetapi diberlakukan undang-undang perkawinan khusus bagi umat Islam. Undang-undang itu ditetapkan oleh pemerintah dan parlemen India setelah musyawarah dengan para mujtahid kaum muslimin yang ada di India. Jika persepakatan para mujtahid India itu dapat dikatakan sebagai ijmak, maka ada kemungkinan terjadinya ijmak pada masa setelah Khalifah Utsman sampai sekarang sekalipun ijmakitu hanya dapat dikatakan sebagai ijmak lokal.

Jika demikian dapat ditetapkan definisi ijmak, yaitu keputusan hukum yang diambil oleh wakil-wakil umat Islam atau para mujtahid yang mewakili segala lapisan masyarakat umat Islam. Karena dapat dikatakan sebagai ulilamri sebagaimana yang tersebut pada ayat 59 surat an-Nisa atau sebagai ahlul halli wal 'aqdi. Mereka diberi hak oleh agama Islam untuk membuat undang-undang atau peraturan-peraturan yang mengatur kepentingan-kepentingan rakyat mereka.

Hal yang demikian dibolehkan dalam agam Islam. Jika agama Islam membolehkan seorang yang memenuhi syarat-syarat mujtahid untuk berijtihad, tentu saja beberapa orang mujtahid dalam suatu negara boleh pula bersama-sama memecahkan permasalahan kaum muslimin kemudian menetapkan suatu hukum atau peraturan. Pendapat sebagai hasil usaha yang dilakukan orang banyak tentu lebih tinggi nilainya dari pendapat yang dilakukan oleh orang seorang. 


\section{Pembagian ijmak}

Sekalipun sukar membuktikan apakah ijmak benar-benar terjadi, namun dalam kitab-kitab fiqh dan ushul fiqh diterangkan macam-macam ijmak. Diterangkan bahwa ijmak itu dapat ditinjau dari beberapa segi dan tiap-tiap segi terdiri atas beberapa macam.

Ditinjau dari segi cara terjadinya, maka ijmak terdiri atas: Ijmak bayani, yaitu para mujtahid menyatakan pendapatnya dengan jelas dan tegas, baik berupa ucapan atau tulisan. Ijmakbayani disebut juga ijmakshahih, ijmak qauli atau ijmak haqiqi (Mubarok, 2002).

Ijmaksukuti, yaitu para mujtahid seluruh atau sebahagian mereka tidak menyatakan pendapat dengan jelas dan tegas, tetapi mereka berdiam diri saja atau tidak memberikan reaksi terhadap suatu ketentuan hukum yang telah dikemukakan mujtahid lain yang hidup di masanya. Ijmakseperti ini disebut juga ijmak 'itibari(Syihab, 2002).

Ditinjau dari segi yakin atau tidaknya terjadi suatu ijmak, dapat dibagi kepada: Ijmakqath' $i$, yaitu hukum yang dihasilkan ijmakitu adalah qath'i diyakini benar terjadinya, tidak ada kemungkinan lain bahwa hukum dari peristiwa atau kejadian yang telah ditetapkan berbeda dengan hasil ijmakyang dilakukan pada waktu yang lain; Ijmak zanni, yaitu hukum yang dihasilkan ijmak itu zanni, masih ada kemungkinan lain bahwa hukum dari peristiwa atau kejadian yang telah ditetapkan berbeda dengan hasil ijtihad orang lain atau dengan hasil ijmakyang dilakukan pada waktu yang lain.

Berdasarkan kitab-kitab fiqh terdapat pula beberapa macam ijmak yang dihubungkan dengan masa terjadi, tempat terjadi atau orang yang melaksanakannya. Ijmak-ijmak itu ialah: Ijmak sahabat, yaitu ijmak yang dilakukan oleh para sahabat Rasulullah (Amrullah,1985). Ijmak khulafaurrasyidin, yaitu ijmak yang dilakukan oleh Khalifah Abu Bakar, Umar, Utsman dan Ali bin Abi Thalib. Tentu saja hal ini hanya dapat dilakukan pada masa ke-empat orang itu hidup, yaitu pada masa Khalifah Abu Bakar. Setelah Abu Bakar meninggal dunia ijmak tersebut tidak dapat dilakukan lagi.

Ijmak shaikhan, yaitu ijmak yang dilakukan oleh Abu Bakar dan Umar bin Khattab; Ijmak ahli Madinah, yaitu ijmak yang dilakukan oleh ulama-ulama Madinah. Ijmak ahli Madinah merupakan salah satu sumber hukum Islam menurut Madzhab Maliki, tetapi Madzhab Syafi'i tidak mengakuinya sebagai salah satu sumber hukum Islam (al-Rahim al-Sayih, 1993).Ijmak ulama Kufah, yaitu ijmak yang dilakukan oleh ulama-ulama Kufah. Madzhab Hanafi menjadikan ijmak ulama Kufah sebagai salah satu sumber hukum Islam (al-Rahim al-Sayih, 1993).

\section{Kontroversi Terjadinya ijmak}

Jika menilik pada syarat-syarat dan rukun ijmak yang begitu kompleks, apakah mungkin ijmak bisa terealisasi? Apabila masih mungkin terjadi, apakah mungkin hasil ijmak itu bisa diketahui?. Apakah mungkin mentransfer hasil ijmak kepada seluruh pihak yang membutuhkan?. Itulah sederet pertanyaan yang muncul ketika kita ditanya tentang posibilitas ijmak.

Secara mengagumkan, Dr. Wahbah Zuhailly mampu menguraikan persoalan yang begitu rumit ini menjadi lebih mudah untuk dipahami. Berikut ini akan kami uraikan sedikit gambaran tentang ulasan beliau (al-Zuhayli, 1986).

a. Kemungkinan ijmak secara adat (sunnatullah).

Dua kutub ulama' kembali berseberangan dalam menaggapi persoalan ini. Sebagian kaum Syi'ah dan Mu'tazilah pesimis bahkan menganggap mustahil ijmakbisa 
terwujud. Namun jumhur ulama' optimis bahwasanya terwujudnya ijmakbukanlah suatu fantasi belaka.Beberapa argumen para pihak yang kontra ijmak adalah;

1.) Sesungguhnya kesepakatan para mujtahid adalah mustahil, sama mustahilnya dengan kesepakatan mereka untuk makan atau bertutur kata yang sama persis dalam satu waktu.Sanggahan; Kesepakatan dalam hukum syari'at bukanlah suatu hal yang mustahil, karena terdapat beberapa faktor yang bisa menyetukan perbedaan pola pikir para mujtahid, yaitu melalui suatu dalil syara' yang jelas. Kemudian dalil inilah yang dijadikan sebagai acuan dasar kesepakatan.

2.) Tersebarnya para mujtahid di berbagai belahan bumi, sehingga menghalangi terjadinya sosialisasi hukum yang akan disepakati (diadakan ijmak). Otomatis ijmakjuga tidak mungkin berhasil.Sanggahan; sesungguhnya pada era permulaan Islam, sosialisasi hukum pada seluruh mujtahid sangatlah mudah, karena jumlah mereka yang terbilang sedikit \& tinggal di daerah-daerah terbatas saja. Sedangkan pada masa kontemporer justru semakin besar kemungkinan terealisasinya ijmak, mengingat kemajuan tekhnologi informasi \& transportasi yang sedemikian pesat.

b. Kemungkinan pengetahuan terhadap ijmakdan melihatnya secara konkret.

Mayoritas ulama' berpendapat; Amat mungkin pengetahuan tentang ijmak bisa diketahui dengan cara mengumpulkan para pemimpin (ولـي الأمسر () pada suatu daerah tertentu, atau dengan cara menulis surat kepada masing-masing pemimpin itu untuk mengatahui pendapatnya, sehingga pendapat mereka bisa diketahui via tulisan.

c. Terjadinya ijmak melalui tindakan nyata

Para jumhur ulama' menunjukkan bukti-bukti berupa ijmakyang pernah dihasilkan oleh para Shahabat RA \& generasi sesudahnya. Contoh ijmak tentang bagian 1/6 yang diperuntukkan bagi nenek dalam masalah waris, ijmaktentang batalnya pernikahan wanita muslimah dengan laki-laki kafir, dll. Semua Ijmak ini didasarkan pada Nash Syara'.

d. Menginformasikan ijmak kepada masyarakat

Menurut Al-Amidie, akar dari perbedaan pendapat dalam poin ini, berkenaan dengan kontroversi sebelumnya, yaitu ; Apakah sah menggunakan Dalil sandaran yang berupa Qiyas atau Hadits Ahad di dalam masalah ijmak.Bagi ulama' yang memperkenankan Qiyas atau Hadits Ahad sebagai Dalil sandaran, maka ulama' itu akan berasumsi bahwa informasi ijmak yang dia peroleh dari individu-individu, bisa dijadikan sebagai hujjah baginya. Sedangkan ulama' yang tidak memperkenankan Qiyas atau Hadits Ahad sebagai Dalil sandaran, maka dia hanya akan mengambil Ijmak para shahabat RA yang dia terima secara mutawattir (alZuhayli, 1986).

Jumhur ulama berpendapat, bahwa ijmak dapat dijadikan argumentasi (hujjah) berdasarkan hadits-hadits yang menyatakan bahwa umat Muhammad tidak akan bersepakat terhadap kesesatan dan apa yang menurut pandangan kaum muslimin baik, maka menurut Allah juga baik. Oleh karena itu, amal perbuatan para sahabat yang telah disepakati dapat dijadikan argumentasi.

Menurut Al-Maidi, para ulama' telah sepakat mengenai ijmak sebagai hujjah yang wajib diamalkan. Pendapat tersebut bertentangan dengan Syi'ah, Khawarij dan Nizam dari golongan Mu'tazilah (al-Khudhari Biek,2007).

Al-Hajib berkata bahwa ijmakitu hujjah tanpa menanggapi pendapat Nizam, Khawarij dan Syiah. Adapun Ar-Rahawi berpendapat bahwa ijmak itu pada dasarnya adalah hujjah. Sedangkan dalam kitab "Qawa'idul Usul dan Ma'qidul Usul" dikatakan bahwa ijmak hujjah pada setiap masa. Namun pendapat itu 
ditentang oleh "Daud" yang mengatakan bahwa ijmak itu hanya terjadi pada masa sahabat(Syafe'i, 2007).

Kehujjahan ijmak juga berkaitan erat dengan jenis ijmakitu sendiri, yaitu sharih dan sukuti, agar lebih jelas maka pendapat mereka tentang ijmak akan ditinjau berdasarkan pembagian ijmak itu sendiri.

a.) Kehujjahan ijmak sharih

Jumhur telah sepakat bahwa ijmak sharih itu merupakan hujjah secara qath'i, wajib mengamalkannya dan haram menentangnya. Bila sudah terjadi ijmak pada suatu permasalahan maka itu menjadi hukum qath' $i$ yang tidak boleh ditentang, dan menjadi menjadi masalah yang tidak boleh diijtihadi lagi.Hal ini berdasarkan QS. An-Nisa' ayat 115.

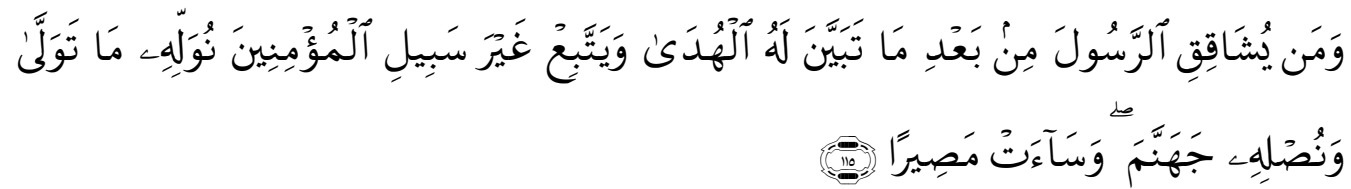

Artinya: "Dan Barangsiapa yang menentang Rasul sesudah jelas kebenaran baginya, dan mengikuti jalan yang bukan jalan orang-orang mukmin, Kami biarkan ia leluasa terhadap kesesatan yang telah dikuasainya itu dan Kami masukkan ia ke dalam Jahannam, dan Jahannam itu seburuk-buruk tempat kembali".

Kehujjahan dalil dari ayat di atas adalah ancaman Allah SWT terhadap mereka yang tidak mengikuti jalannya orang-orang mukmin. Disebutkan bahwa mereka akan dimasukkan ke neraka Jahanam dan akan mendapat tempat kembali yang buruk. Hal itu menunjukkan bahwa jalan yang ditempuh oleh orang-orang yang tidak beriman itu adalah batil dan haram diikuti. Sebaliknya, jalan yang ditempuh oleh orang-orang mu'min adalah hak dan wajib diikuti.

b.) Kehujjahan ijmak sukuti

Ijmak sukuti telah dipertentangkan kehujjahannya di kalangan para ulama. Sebagian dari mereka tidak memandang ijmak sukuti sebagai hujjah bahkan tidak mengatakan sebagai ijmak. Di antara mereka ialah pengikut Maliki dan Imam Syafi'i yang menyebutkan hal tersebut dalam berbagai pendapatnya(Syarifuddin, 2009). Mereka berargumen bahwa diamnya sebagian mujtahiditu mungkin saja menyepakati sebagian atau bisa saja tidak sama sekali. Misalnya karena tidak melakukan ijtihad pada satu masalah atau takut mengemukakan pendapatnya sehingga kesepakatan mereka terhadap mujtahid lainnya tidak bisa ditetapkan apakah hal itu qath'i atau zanni. Jika demikian adanya, tidak bisa dihalalkan adanya kesepakatan dari seluruh mujtahid. Berarti tidak bisa dikatakan ijmak ataupun dijadikan sebagai hujjah.

Sebagian besar golongan Hanafi dan Imam Ahmad bin Hambal menyatakan bahwa ijmak sukuti merupakan hujjah qath'i seperti halnya ijmak sharih. Alasan mereka adalah diamnya sebagian mujtahid utuk menyatakan sepakat ataupun tidaknya terhadap pendapat yang dikemukakan oleh sebagian mujtahid lainnya, bila memenuhi persyaratan adanya ijmak sukuti, bisa dikatakan sebagai dalil tentang kesepakatan mereka terhadap hukum. Dengan demikian, bisa juga dikatakan sebagai hujjah yang qath'i karena alasannya juga menunjukkan adanya ijmak yang tidak bisa dibedakan dengan ijmak sharih.

\section{Contoh perselisihan pendapat yang disebabkan oleh kontroversi ijmak}

Sejarah tasyri' Islam telah menorehkan tintanya bahwa ijtihad pernah terjadi di masa kekhalifahan Abu Bakar dan Umar dan tidak seorangpun sahabat yang 
menafikan kenyataan itu. Sebagaimana yang diriwayatkan oleh Maimun bin Mahran bahwa jika khalifah Abu Bakar dan Umar dihadapkan dengan suatu pertentangan atau masalah, maka akan mencari jawabannya di dalam al-Qur'an atau sunnah Nabi, dan jika tidak menemukan jawaban maka mereka akan memanggil dan mengumpulkan para tokoh kaum muslimin pada saat itu dan para ulama' untuk diajak musyawarah, berijtihad dan mencari jawaban, dan hal ini juga dikatakan oleh al-Juwaini. Dan merupakan bukan hal yang meragukan lagi bahwa pada waktu itu tidak semua para ulama' yang dikumpulkan, karena para ulama' tidak dalam satu tempat tetapi tersebar di berbagai daerah seperti di Makkah, di Syam dan di Yaman dan jika menunggu keseluruhan para ulama' terkumpul maka akan membutuhkan waktu yang lama.

Contoh ijmak yang dilakukan pada masa sahabat seperti ijmak yang dilandaskan pada al-Qur'an adalah kesepakatan para ulama' tentang keharaman menikahi nenek dan cucu perempuan berdasarkan QS. An-Nisa' ayat 23. Para ulama' sepakat bahwa kata ummahat(para ibu) dalam ayat tersebut mencakup ibu kandung dan nenek, sedangkan kata banat (anak-anak wanita) dalam ayat tersebut mencakup anak perempuan dan cucu perempuan(al-Khudhari Biek, 2007).

Sebagaimana dijelaskan di atas, bahwa jika ada masalah yang tidak ditemukan jawabannya baik dalam al-Qur'an maupun Sunah maka bermusyawarah dengan para ulama' untuk menyelesaikan permasalahan tersebut. Seperti khalifah Umar ketika itu mengumpulkan para sahabat untuk membahas masalah pembagian penghasilan hasil bumi Irak dan tanah-tanah taklukan lainnya yang merupakan ghanimah perang. Ternyata mereka sepakat untuk membiarkan tanah itu diolah penduduk aslinya dan tidak membagikannya kepada para pasukan. Demikianlah yang mereka lakukan sepanjang masa hayat hingga masa itu berganti dan orang-orang sepeninggal mereka menjalankan apa yang telah disepakati.

\section{Prosedur Menyelesaikan Kasus Hukum dengan Ijmak}

Pada periode modern, pemikir-pemikir Muslim mengembangkan konsep ijmakdengan berbagai kemungkinan baru yang selaras dengan kondisi modern. Muhammad Iqbal, misalnya, mengungkapkan gagasannya tentang ijmak sebagai transfer kekuasaan ijtihad dari individu yang mewakili mazhab-mazhab yang terorganisasi ke dalam bentuk "institusi legislatif permanen" atau majelis perwakilan rakyat. Dengan mentransfer ijtihad kepada lembaga legislatif, yang bisa saja beranggotakan Muslim awam atau bahkan nonmuslim, Iqbal tentu saja tidak memberikan kualifikasi apapun untuk pelaksanaan ijtihad, kecuali memiliki wawasan yang tajam dalam masalah hukum.

Konsensus atau ijmakselama berabad-abad telah menjadi validasi terpenting berbagai keputusan di dalam Islam, khususnya di kalangan Sunni. Nabi Muhammad dikabarkan pernah bersabda: Umatku tidak akan bersepakat dalam kekeliruan. Berpijak pada hadits inilah otoritas ijmakyang mengikat itu disandarkan. Bahkan, di kalangan Sunni, otoritas final untuk penafsiran keagamaan diletakkan pada konsensus (ijmak) atau putusan kolektif masyarakat muslim. Implikasinya, konsensus memainkan peran penting dalam perkembangan Islam dan memberi andil yang signifikan terhadap penafsirannya.

Tetapi, dalam konsep tradisional, hanya 'ulama' yang memiliki peran dalam mencapai konsensus. Masyarakat pada umumnya tidak begitu diperhitungkan. Dengan demikian, ijmaklebih bersifat elitis. Selain itu, masih dalam konsepsi klasik, ijmak berorientasi ke belakang: dalam kesepakatan ulama di masa-masa silam. Bahkan, di kalangan mazhab Islam tertentu, ijmakdibatasi pada konsensus para sahabat Nabi. Ijmakapapun yang datang setelah itu tidak memiliki nilai mengikat, terlebih lagi jika ia merativikasi doktrin yang bertentangan dengan tradisi salaf. 
Gagasan ijmak yang agak luas dikemukakan al-Syafi'i dan belakangan oleh alGhazali. Bagi keduanya, ijmakadalah kesepakatan kaum Muslimin secara menyeluruh. Gagasan ini jelas bersifat utopis, karena tidak ada kesepakatan umat Islam yang bulat atau menyeluruh sepanjang sejarah Islam. Yang ada hanyalah kesepakatan mayoritas, bahkan di tingkat lokal (Hasan,1985).

Pada periode modern, pemikir-pemikir Muslim mengembangkan konsep ijmakdengan berbagai kemungkinan baru yang selaras dengan kondisi modern. Muhammad Iqbal, misalnya, mengungkapkan gagasannya tentang ijmaksebagai transfer kekuasaan ijtihad dari individu yang mewakili mazhab-mazhab yang terorganisasi ke dalam bentuk "institusi legislatif permanen" atau majelis perwakilan rakyat.Dengan mentransfer ijtihad kepada lembaga legislatif, yang bisa saja beranggotakan Muslim awam atau bahkan nonmuslim, Iqbal tentu saja tidak memberikan kualifikasi apapun untuk pelaksanaan ijtihad, kecuali memiliki wawasan yang tajam dalam masalah hukum. Tetapi, untuk menghindari kemungkinan terjadinya salah tafsir terhadap sumber-sumber Islam, Iqbal menyetujui masuknya ulama ke dalam majelis untuk membantu dan memimpin perbincangan-perbincangan bebas tentang masalah yang bertalian dengan Islam.

Sarjana pemikir neo-modernis asal pakistan, Fazlur Rahman mengungkapkan kemungkinan baru ijmakdalam masyarakat kontemporer. Baginya, ijtihad yang dihasilkan individu atau kelompok kerja akan mengkristal ke dalam ijmak setelah melalui interaksi ide yang ketat. Dengan demikian, ijmakyang merupakan konsensus mayoritas masyarakat lebih bersifat dinamis, berorientasi ke depan, dan tidak monolitik. Golongan minoritas yang merasa ijtihad-nya lebih mendekati kebenaran, terbuka sepenuhnya untuk meyakinkan masyarakat akan kebenaran gagasannya. Apabila masyarakat telah menerima gagasan minoritas secara mayoritas, opini itu membentuk ijmak baru dan menggantikan ijmaklama. Aktivitas untuk menggalang konsensus masyarakat ini, menurut Rahman, dirujuk al-Quran dengan terma syura.

Pada level negara, ijmak masyarakat akan ditempa atau dirumuskan ke dalam bentuk hukum dan perundang-undangan oleh lembaga legislatif, yang disebut Rahman sebagai lembaga syura-ijmak. Dalam pandangan Rahman, majelis ini dipilih oleh rakyat tanpa kualifikasi teknis apapun. Dalam masalah-masalah pelik, majelis dapat meminta advis kepada para ahli. Undang-undang atau hukun yang ditetapkan majelis bisa saja benar atau keliru. Tetapi, sepanjang hukum tersebut mencerminkan kehendak masyarakat, ia tetap bersifat islami dan demokratis karena merepresentasikan ijmakmasyarakat. Selain itu, ada kemungkinan untuk mengubah konsensus tersebut, karena secara potensial selalu terdapat kemungkinan bagi pandangan minoritas untuk menjadi mayoritas melalui proses perdebatan.

Rahman bahkan mengelaborasi konsepnya tentang lembaga syura-ijmakini ke dalam suatu majelis internasional yang beranggotakan majelis legislatif negeri-negeri Muslim. Tugasnya adalah memberi advis yang selanjutnya akan dirumuskan ke dalam undang-undang oleh majelis nasional negeri-negeri Muslim berdasarkan sinaran perbedaan regional dan situasi sosial masing-masing negeri.

Survei singkat di atas memperlihatkan bahwa ijmakbisa memberikan pijakan yang efektif untuk menerima kekuasaan mayoritas (majority rule). Sejalan dengan ini, Louay M. Safi juga mengemukakan bahwa legitimasi negara tergantung pada sampai sejauh mana organisasi dan kekuasaan negara merefleksikan kehendak masyarakat, seperti ditegaskan para yuris klasik, legitimasi institusi negara tidak terambil dari sumber-sumber tekstual, tetapi didasarkan terutama pada prinsip ijmak . Dengan kata lain, ijmakbisa memberi kemungkinan legitimasi demokrasi bagi kaum Muslimin dan menawarkan format institusi dan prosedur untuk menjalankannya. 
Mekanisme ijmakyang telah diuraikan juga memberikan kemungkinan deliberasi dan perdebatan publik, sehingga berbagai sudut pandang yang berkembang dan dikembangkan secara individual ataupun kolektif mendapat kesempatan untuk didengar sebelum masyarakat akhirnya secara konsensus atau mayoritas memilih yang dianggap laik. Ketika putusan mayoritas tercapai, seluruh anggota masyarakat, baik Muslim ataupun non Muslim, harus berupaya mengejawantahkannya ke dalam praktik. Penggagas, pengikut atau yang menyetujui pandangan minoritas juga harus menerima keputusan mayoritas dan berupaya mengimplementasikannya sebagai suatu konsensus.

Mekanisme ijmak semacam ini menggagaskan keterlibatan seluruh anggota masyarakat, termasuk bukan muslim, dalam proses pengambilan keputusan. Tidak ada yang aneh dalam hal ini. Hasan al-Banna, dalam risalah Nahwa an-Nur (1936), mensinyalir ada orang menganggap bahwa dengan menjadikan Islam sebagai landasan kehidupan, maka hal ini berarti minoritas nonmuslim tidak dapat hidup di lingkungan umat Islam dan persatuan di antara berbagai unsur masyarakat tidak mungkin tercapai. Menurut al-Banna, anggapan semacam itu berseberangan dengan prinsip persamaan dan pengakuan Islam terhadap minoritas nonmuslim. Agama Islam, menurutnya, mengkuduskan kesatuan kemanusiaan umum (al-wahdah al-insaniyyah al-'ammah), kesatuan keagamaan umum (al-wahdah al-diniyyah al-'ammah), dan kesatuan keagamaan khusus umat Islam (al-wahdah al-diniyyah al-khassah). Implementasi prinsip-prinsip ini, menurut al-Banna, tidak akan menimbulkan perpecahan, malahan menjadikan persatuan berdimensi sakral dan religius.

Senada dengan itu, Fazlur Rahman menekankan sikap anti-eksklusivisme Islam sehubungan dengan komunitas-komunitas keagamaan lainnya, berdasarkan sejumlah ayat al-Quran (2:62 dan 5:69), yang menurut tafsiran Rahman mengungkapkan siapa pun yang percaya kepada monoteisme dan hari akhirat, serta melakukan perbuatan baik akan selamat. Dalam negara modern, seluruh warga negara harus dipandang setara satu sama lain, tanpa diskriminasi antara sesama warga, baik Muslim atau bukan Muslim.

Pandangan-pandangan kesarjanaan Muslim yang dikemukakan di atas dengan jelas menyepakati kesetaraan warga negara baik Muslim atau nonmuslim serta persamaan hak dan kewajibannya, termasuk dalam proses pencapaian konsensus. Karena itu, ketika suatu ijmakmengkristal atau berhasil dicapai dalam komunitas tersebut, berdasarkan prinsip mayoritas, ia mengikat seluruh anggotanya tanpa kecuali.

Sebagaimana disinggung di atas, konsensus atau ijmakmasyarakat inilah yang kemudian diundangkan oleh lembaga perwakilan rakyat di tingkat lokal atau nasional. Majelis semacam ini yang dibentuk misalnya lewat pemilihan umum tentunya merupakan representasi masyarakat yang menerjemahkan kepentingan masyarakat ke dalam kebijakan-kebijakan yang koheren dan konsisten (preference representation). Tetapi, sebagai himpunan orang terpilih, majelis ini juga bisa mempengaruhi preferensi publik (preference formation), jika suatu masalah dinilai layak untuk dirumuskan ke dalam kebijakan. Untuk pembentukan preferensi ini, deliberasi, advokasi, pengajuan rancangan undang-undang, serta cara-cara lainnya yang melibatkan masyarakat, penting dilakukan majelis. Aktivitas semacam inilah yang dimaknai Rahman dengan istilah syura.

Salah satu cara yang dapat ditempuh untuk membentuk konsensus masyarakat atau untuk menakar kesepakatan masyarakat mengenai suatu hal adalah melalui referendum. Ijmak, berdasarkan alur logika yang telah dikemukakan, jelas bisa 
mengambil bentuk referendum. Partisipasi masyarakat yang luas dalam penentuan suatu kebijakan sangat bisa diharapkan dalam implementasi ijmakreferendum ini.

Pada level regional atau internasional, konvensi-konvensi yang telah dirativikasi suatu negara muslim juga merupakan bentuk lain dari perluasan konsep ijmak. Dengan merativikasi konvensi semacam itu, negara muslim tersebut terikat kesepakatan atau ber-ijmak untuk melaksanakannya.Dalam hal ini, ijma sebagai doktrin Islam klasik mungkin tidak dapat dipertahankan, namun konsep tersebut pasti memiliki relevansi sebagai metode dan institusi, yang Muslim harus menemukan cara untuk membuat praktis. Dengan demikian, umat Islam perlu teliti mendedikasikan kembali diri mereka untuk mempraktekkan Islam dan menjalani hidup mereka menurut cara yang dinamis, pemecahan masalah, bukan membuta mengikuti dogma kaku atau memanjakan diri legalisme.

\section{Kesimpulan}

Berdasarkan pembahasan di atas, maka dapat disimpulkan bahwa para ulama sepakat bahwa ijmak merupakan dasar pengambilan hukum setelah al-Qur'an dan hadits Nabi.Mengingat pada zaman sekarang ini permasalahan umat semakin kompleks dan membutuhkan jawaban cepat maka ijmak dapat dilakukan untuk penyelesaian permasalahan tersebut. Prosedur menyelesaikan kasus hukum dengan ijmak yaitu konsensus memainkan peran penting dalam perkembangan Islam dan memberi andil yang signifikan terhadap penafsirannya. Salah satu cara yang dapat ditempuh untuk membentuk konsensus masyarakat atau untuk menakar kesepakatan masyarakat mengenai suatu hal adalah melalui lembaga syura atau musyawarah.

\section{DAFTAR PUSTAKA}

Abd al-Rahim al-Sayih, Ahmad. 1993. Risalah fi Ri'ayah al-Maslahah. Mesir: al-Dar alMisriyah al-Lubnaniyah.

Abu Zahrah,Muhammad. 2010. Ushul Fiqih, terj. Saefullah Ma'shum et, al. Jakarta: Pustaka Firdaus.

Al 'Alwani, Taha Jabir. 1990.Ushul Al Fiqh al-Islami: Source Methodology In Islamic Jurisprudence. Virginia USA: The International Institute of Islamic Thought.

Al-Khudari Biek, Muhammad. 2007. Ushul Fiqih, terj.Faiz el Muttaqin. Jakarta: Pustaka Amani.

Al-Zuhayli, Wahbah.1986.Us $\}$ u $>$ l al-Figh Al-Islami. II . Beirut: Dar al-Fikr.

Amrullah,Abdul Karim. 1985.Pengantar Ushul Fiqh. Jakarta: Pustaka Panjimas.

Hasan,Ahmad. 1985. Ijmak, terj. RahmaniAstuti. Bandung: Pustaka.

Mubarok, Jaih. 2002.Metodologi Ijtihad Hukum Islam. Yogyakarta: UII Press.

Rosyada, Dede. 1996.Hukum Islam Dan Pranata Sosial. Jakarta: PT Raja Grafindo Persada.

Syafe'i, Rachmat.2007.Ilmu Ushul Fiqih. Bandung: Pustaka Setia.

Syahar,Saidus.1999.Asas-asas Hukum Islam. Bandung: Alumni.

Syarifuddin,Amir.1999.Ushul Fiqh jilid 2. Logos Wacana Ilmu.

Syihab, Umar. 2002. Hukum Islam dan Transformasi Pemikiran. Semarang: Dina Utama

Semarang.

Umar, Muin. 1985.Ushul Fiqh I . Jakarta: Departemen Agama RI.

Wahab Khallaf, Abdul.1999.Ilmu Usul Fikih, terj, Halimuddin. Jakarta: Rineka Cipta. 